\title{
Review \\ Designing Advanced Biomedical Biodegradable Mg Alloys: A Review
}

\author{
Murtatha M. Jamel ${ }^{1, *}$, Mostafa M. Jamel ${ }^{2}$ and Hugo F. Lopez ${ }^{1}$ \\ 1 Department of Materials Science and Engineering, University of Wisconsin-Milwaukee, \\ Milwaukee, WI 53211, USA; hlopez@uwm.edu \\ 2 Independent Researcher, Chicago, IL 60607, USA; eng.murtatha@gmail.com \\ * Correspondence: aalkumail@gmail.com
}

check for updates

Citation: Jamel, M.M.; Jamel, M.M.;

Lopez, H.F. Designing Advanced

Biomedical Biodegradable Mg Alloys:

A Review. Metals 2022, 12, 85.

https://doi.org/10.3390/met12010085

Academic Editor: Changdong Gu

Received: 10 October 2021

Accepted: 17 December 2021

Published: 4 January 2022

Publisher's Note: MDPI stays neutral with regard to jurisdictional claims in published maps and institutional affiliations.

Copyright: (C) 2022 by the authors. Licensee MDPI, Basel, Switzerland. This article is an open access article distributed under the terms and conditions of the Creative Commons Attribution (CC BY) license (https:// creativecommons.org/licenses/by/ $4.0 /)$.

\begin{abstract}
The increased demand for alloys that can serve as implantation devices with outstanding bio-properties has led to the development of numerous biomedical Mg-based alloys. These alloys have been extensively investigated for their performance in living tissue with mixed results. Hence, there are still major concerns regarding the use of magnesium alloys for such applications. Among the issues raised are elevated corrosion rates, hydrogen generation, and the maintenance of mechanical integrity for designated healing times. In addition, toxicity can arise from the addition of alloying elements that are intended to improve the mechanical integrity and corrosion resistance of $\mathrm{Mg}$ alloys. The current work reviews the recent advances in the development of $\mathrm{Mg}$ alloys for applications as bio-absorbable materials in living organic environments. In particular, it attempts to develop a roadmap of effective factors that can be utilized when designing $\mathrm{Mg}$ alloys. Among the factors reviewed are the effects of alloying additions and processing methods on the exhibited mechanical properties and corrosion rates in simulated bio-fluids used in biomedical applications.
\end{abstract}

Keywords: magnesium alloys; alloying elements; processing methods; heat treatments; mechanical properties; corrosion of magnesium; biomedical metals

\section{Introduction}

It is known that magnesium $(\mathrm{Mg})$ exhibits good biocompatibility in the human body with high allowable daily dosages (240-420 mg/day) and no systemic toxicity or infection effects. Additionally, the density of $\mathrm{Mg}$ and its alloys $\left(1.73-1.85 \mathrm{~g} / \mathrm{cm}^{3}\right)$ is close to that of the cortical bone $\left(1.75 \mathrm{~g} / \mathrm{cm}^{3}\right)$. Moreover, the Mg elastic modulus (41-45 GPa) is closer to natural bone (3-20 GPa) when compared with other metals, such as tin. Tin has a Young modulus of approximately $49.9 \mathrm{GPa}$; however, because of its toxicity and high density, it cannot be used as a biomaterial. Other metals, such as titanium alloys (TiAl6V4), with an elastic modulus of around $110 \mathrm{GPa}$ and a density of around $4.5 \mathrm{~g} / \mathrm{cm}^{3}$, are used as biomaterials. However, the larger difference in Young modulus and the resulting difference in stiffness deteriorate the problem of stress shielding and bone resorption. Comparatively speaking, using Mg reduces bone stress shielding within the human body [1,2]. Other approaches have been used to address this challenge, such as the use of different biocompatible materials, and a combination of metals has also been considered for applications in this field [3-26]. Nonetheless, using Mg and its alloys remains the easiest approach.

It was reported that $\mathrm{Mg}$ possesses an elastic modulus comparable to other metallic materials but with a lower density, and, hence, it has the highest specific strength [27]. The magnesium crystal structure is hexagonal close packed (HCP). Thus, it is not a very ductile metal, as its slip planes do not intersect with each other.

In addition to its effect on mechanical properties, the effect of planes and crystal orientation is also present in the corrosion properties of $\mathrm{Mg}$. Even though the $\mathrm{Mg}$ corrosion potential is $-2.37 \mathrm{~V}$, different crystal planes show different corrosion properties of the exposed grain. Depending on the medium used, open-circuit corrosion is the greatest 
near the orientation of $\{0001\}$. Especially in $\mathrm{Cl}$ containing corrosion media, this could be attributed to the thickness of the oxide layer, which is the thinnest on (0001). Furthermore, open-circuit corrosion for certain crystallographic planes correlates with the surface energy of these faces [28]. For example, as-cast magnesium exhibits a fast degradation rate of $2.89 \mathrm{~mm} /$ year in $0.9 \% \mathrm{NaCl}$ solution $[1,2,29]$.

The yield strength, ultimate tensile strength (UTS), and elongation are $27.5 \mathrm{MPa}$, 97.5 $\mathrm{MPa}$, and 7.31\%, respectively [30]. Moreover, the lack of enough slip systems in $\mathrm{Mg}$ makes its formability at room temperature rather poor as a result of slip localization and the buildup stresses at grain boundaries [31]. However, the low density of $\mathrm{Mg}$ combined with its high specific strength, high damping capacity, good biocompatibility, and reduced stress shielding makes $\mathrm{Mg}$ and its alloys ideal candidates for biomedical applications. Nevertheless, further work on $\mathrm{Mg} / \mathrm{Mg}$ alloys is needed to improve their performance in living organic fluids, including their mechanical integrity. Efficient degradation of these alloys should be able to combine rate alloy dissolution with no deterioration of their mechanical integrity, which is in agreement with the time required for bone healing in orthopedic applications [32]. Figure 1 shows the microstructure of pure magnesium.

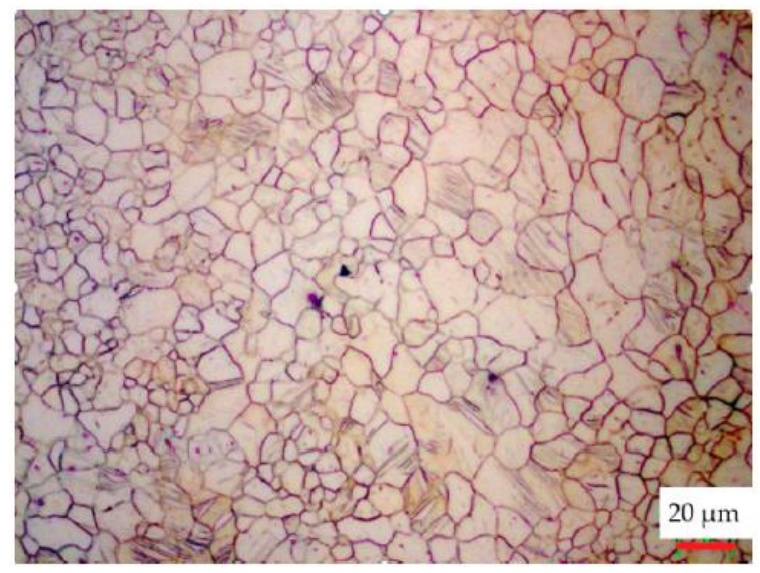

Figure 1. Microscope image of pure magnesium microstructure quenched in liquid $\mathrm{CO}_{2}$ at $500 \times$.

Alloy corrosion plays a significant role in defining effective metals and alloys for multiple applications, such as in the biomedical, automotive, aerospace, and electronics sectors. Numerous corrosion studies have been carried out on diverse metals and alloys aimed at monitoring, testing, and improving their corrosion performance in aggressive environments [1,33-37]. In general, the corrosion process can be identified as the degradation of a metal via an electrochemical reaction with the environment. Pure magnesium has a high corrosion rate, which is attributed to the low Pilling-Bedworth ratio $(\sim 0.81)$ of the passive film in the presence of moisture. In addition, the lack of film regeneration coupled with the high $\mathrm{Mg}$ electronegativity [31] accounts for the high metal corrosivity. Moreover, the oxidation reaction of $\mathrm{Mg}$ with the cathodic reaction in water leads to the generation of hydrogen gas. Equations (1)-(4) describe the anodic and cathodic reactions, including the reaction products, as well as the overall $\mathrm{Mg}$ reactions in water. Note that the dissolution of magnesium is described by the anodic reaction (Equation (1)) and hydrogen evolution by the cathodic reaction (Equation (2)), whereas the formation of the passive film is described by Equation (3) [38-40].

$$
\begin{gathered}
\text { Oxidation reaction: } \mathrm{Mg} \rightarrow \mathrm{Mg}^{2+}+2 \mathrm{e}^{-},\left(\mathrm{E}_{\mathrm{o}}=-2.363 \mathrm{~V}\right) \\
\text { Reduction reaction: } 2 \mathrm{H}_{2} \mathrm{O}+2 \mathrm{e}^{-} \rightarrow \mathrm{H}_{2}(\mathrm{~g})+2\left(\mathrm{OH}^{-}\right),\left(\mathrm{E}_{\mathrm{O}}=+0.826 \mathrm{~V}\right) \\
\text { Product formation: } \mathrm{Mg}^{2+}+2\left(\mathrm{OH}^{-}\right) \rightarrow \mathrm{Mg}(\mathrm{OH})_{2} \\
\text { Overall reaction: } \mathrm{Mg}+2 \mathrm{H}_{2} \mathrm{O}=\mathrm{Mg}(\mathrm{OH})_{2}+\mathrm{H}_{2}(\mathrm{~g}),\left(\mathrm{E}_{\mathrm{O}}=-1.065 \mathrm{~V}\right)
\end{gathered}
$$




\section{Corrosion}

As for other structural materials, the very important limitation of Mg-based alloys as a biodegradable material is their accelerated corrosion. Corrosion is accompanied by the generation of hydrogen gas, which, in extreme cases, can create detrimental health risks (in in vivo conditions) in the form of gas embolism. Here, hydrogen gas can penetrate the bloodstream [41-43]. Therefore, various corrosion tests should be used to verify the suitability of different materials in biomedical material applications, for example, mass loss, $\mathrm{pH}$ monitoring (observation of $\mathrm{pH}$ level change), and electrochemical measurements. As expected, various corrosion products may occur. In the next section, different products are addressed.

\subsection{Corrosion Products}

The composition of the passive layer in Mg alloys is, depending on the environment, predominantly composed of magnesium oxide, magnesium carbonate, and hydroxyapatite (magnesium appetite). However, the incubation time for the formation of the passive film is strongly dependent on the type of environment and alloying additions. Nevertheless, it was proposed that the passive layer is a result of the interaction between $\mathrm{Mg}$ ions with solution ions. Additionally, other chemical entities are present. For example, biological incubation solutions, such as simulated body fluid (SBF) and Hank's solution, contain calcium, carbonate, and phosphate ions.

Among the reactions that account for the passive films developed in $\mathrm{Mg}$ and $\mathrm{Mg}$ alloys $[33,34]$ are the following:

$$
\begin{aligned}
\mathrm{Mg}^{2+}+\mathrm{Ca}^{2+}+\left(\mathrm{PO}_{4}\right)^{3-} & =\mathrm{Ca}_{3} \mathrm{Mg}_{3}\left(\mathrm{PO}_{4}\right)_{4} \\
\mathrm{Mg}^{2+}+\left(\mathrm{CO}_{3}\right)^{2-} & =\mathrm{MgCO}_{3}
\end{aligned}
$$

It is worth mentioning that carbonates, $\left(\mathrm{CO}_{3}\right)^{2-}$ Equation (6), promote $\mathrm{Mg}$ dissolution and rapid surface passivation. This happens due to the precipitation of magnesium carbonate, as well as the fact that sulfate ions are more aggressive than chloride ions in the case of general corrosion [35].

Although the charge of both the anodic and cathode reactions is similar, hydrogen gas generation does not describe the actual corrosion rate, as part of the hydrogen is dissolved in the biological/corrosion environment. Alternatively, not all of the $\mathrm{Mg}$ dissolves, and some of the species give rise to insoluble corrosion products. Various corrosion tests are used to evaluate the corrosion process, because an individual corrosion test is insufficient to provide enough information on the corrosion behavior of $\mathrm{Mg}$ alloys.

Depending on the environment, there is a certain tolerance limit to hydrogen generated due to corrosion. In particular, the biological environment might be able to tolerate slow hydrogen gas generation. The tolerance limit depends on the solubility and diffusivity of the hydrogen gas in the biological environment, as hydrogen has high solubility in fat tissue and fast diffusivity through the skin $[1,36,37]$.

\subsection{Effect of Impurities}

There are various reasons as to why certain alloying elements are added to Mg. Firstly, alloying elements are added to enhance the mechanical properties of $\mathrm{Mg}$ alloys. By doing this, it can meet the weight support requirements. Secondly, they are added to control the corrosion rate of the alloy in a way that the alloy would corrode at a certain rate that corresponds to the healing time of the wound. Accordingly, the appropriate corrosion rate should be determined by the healing rate of the wound.

The corrosion rate depends on the balance in the reaction at the anode and cathode formed by $\mathrm{Mg} / \mathrm{Mg}$ alloy couples in any given environment. Any imbalance in the dynamics between these two couples-healing vs. corrosion-leads to a breakdown that is represented by mechanical failure due to excessive corrosion or to a very slow corrosion that requires surgery to remove the alloy. 
In any case, it has been observed that $\mathrm{Mg}$ tends to corrode non-uniformly because of impurities and second phases. While reaction kinetics increase in the presence of alloying/impurity traces of small overpotential elements, such as iron and nickel, they decrease in the presence of elements with large overpotentials, such as zinc. In the case of $\mathrm{Mg}$ and its alloys, common impurities are highly noble and act as local cathodes to the base metal $(\mathrm{Mg})$, which acts as an anode. The bigger the difference in nobility between $\mathrm{Mg}$ and the other elements is the more severe the corrosion. The severity of corrosion is also partly controlled by the relative surface area between phases. For a specific ratio, there is a certain tolerance limit that, when exceeded, might lead to accelerated corrosion dynamics. Thus, exceeding the tolerance limit of impurities is highly detrimental to the corrosion resistance of magnesium. It is so detrimental that the existence of certain impurities can significantly increase the corrosion rate up to 100 times. This increase in corrosion rate correlates with increases in the hydrogen evolution reaction. This, in turn, limits the safety of the materials used for biomedical applications. Nonetheless, in different biomaterials, different impurity types lead to different evolution rates. This is governed by the type of the impurity, the material, and the materials' degree of purity. Accordingly, different impurities have different maximum allowable levels. For example, iron impurities should not exceed 45 ppm in high purity $\mathrm{Mg}$ or $280 \mathrm{ppm}$ in low purity Mg [1,33,37-39]. In summary, depending on the purity of $\mathrm{Mg}$, the tolerance limit of impurities in $\mathrm{Mg}$-based alloys must not exceed the range of 30-50 ppm for iron, 20-50 ppm for nickel, and 100-300 ppm for copper [39].

\subsection{Corrosion Environments}

The type of the biological corrosion fluid plays a significant role in the corrosion process of biomedical alloys for implant devices. Various studies have concluded that the corrosion rate depends on the type of the corrosion media and the duration of testing. Therefore, different solutions have been used to test the corrosion behavior of magnesium and its alloys, such as Hank's balanced salt solution (HBSS), simulated body fluid (SBF), Dulbecco's modified Eagle's medium (D-MEM), Kokubo solution, phosphate-buffered saline (PBS), artificial plasma (AP), Nor's solution (NS), and $\mathrm{NaCl}$ solutions, in different concentrations $[1,33,37,44]$. Considering these different studies, it has been found that testing the same type of alloy in different solutions and biological environments results in different degradation rates. For instance, a corrosion rate of AZ31 as cast was around $2 \mathrm{~mm} /$ year in SBF but less than $0.7 \mathrm{~mm} /$ year in in vivo tests. This can be ascribed to different reasons related to the identity of the solution. For example, in vivo environments are generally less aggressive than the other corrosion solutions $[33,35,45]$.

Zeng et al. [35] studied the influence of glucose on the corrosion rate of pure magnesium in saline and Hank's solutions at $37^{\circ} \mathrm{C}$. It is known that the effect of glucose in increasing or decreasing the corrosion rate depends on the type of corrosion media. On one hand, increasing glucose content in saline solution decreases both corrosion resistance and $\mathrm{pH}$. This happens due to the formation of gluconic acid from the existing glucose. After the formation of gluconic acid, the acid attacks the metal oxide and attracts chloride ions to cluster on the interface between the metal surface and saline solution. Then, these chloride ions destabilize the surface layer, and by doing this, they cause pitting corrosion. On the other hand, the corrosion rate is decreased by the addition of glucose as a result of the formation of calcium phosphate.

Another important factor that plays a role in the corrosion behavior is the change in $\mathrm{pH}$ value. During the corrosion of magnesium, the $\mathrm{pH}$ value tends to shift toward more alkalinity. This is due to the generation of hydrogen, which promotes an increase in the $\mathrm{pH}$ number. The shift in the basicity degree is also due to the combined effect of anodic and cathodic reactions, where the reaction of anodic products $\left(\mathrm{Mg}^{2+}\right.$ ions) with water deposits $\mathrm{H}_{2}$ gas and hydroxyl $\left(\mathrm{OH}^{-}\right)$ions into the solution. The neutral products of the anodic reaction $\left(\mathrm{Mg}^{2+}\right.$ cations) cannot counterbalance that shift. As a result, the $\mathrm{pH}$ might shift up to more than 10 in non-buffered solutions $(3 \% \mathrm{NaCl})$. The extent of shifting 
depends on the type and presence of alloying elements. Moreover, the increase in the $\mathrm{pH}$ number at the interface between the alloy and the environment can enhance the formation of more stable and protective films. Generally, the formed layers consist of $\mathrm{Mg}(\mathrm{OH})_{2}$ and $\mathrm{CaP}[36,37,46,47]$. The reduction in the corrosion rate at increasing $\mathrm{pHs}$ can be explained by the Pourbaix diagram for $\mathrm{Mg}$, where increasing the $\mathrm{pH}$ induces the passivation of $\mathrm{Mg}$ and leads to enhanced corrosion resistance.

\section{Mg Alloying Systems}

Different mechanisms have been investigated in order to improve the mechanical and corrosion properties of $\mathrm{Mg}$ and its alloys. These methods can be classified into five main groups: (a) the intentional addition of alloying elements, (b) processing methods, (c) applying coatings, (d) solidification, and (e) heat treatments [1,29,46,48-51]. Adding alloying elements can be divided into four categories in magnesium alloys: commercial $\mathrm{Mg}$ alloys, $\mathrm{Mg}$ alloys containing rare-earth elements (REEs), $\mathrm{Mg}$ alloys with nontoxic elements, and $\mathrm{Mg}$ alloys containing a mixture of different alloying systems $[37,45,52]$. In any case, the preferred atomic size of alloying elements is in the range of $\pm 15 \%$ of the atomic diameter of magnesium $(0.320 \mathrm{~nm})[1]$.

Published works on the performance of $\mathrm{Mg}$ alloys suggest that $\mathrm{Mg}$ alloys are potentially viable bio-absorbable materials for implant applications. However, the experimental outcome is controversial, as some of these alloys can exhibit poor biocompatibility due to increased toxicity within the living environment. Recently, $\mathrm{Mg}$ alloys have been fabricated in the forms of stents, screws, pins, and devices for orthopedic applications. The required time to maintain the achieved mechanical stability is estimated to be 12-18 weeks for bone implantations, 6-12 months for stents, and 12-24 months for vessels. Chen et al. [1] reviewed the recent developments of $\mathrm{Mg}$ alloys for bioabsorbable medical implants. The study highlighted the different biomedical applications of $\mathrm{Mg}$ and the importance of considering the required healing time for each medical application. Witte et al. [45,53] studied the biological inflammatory response of a magnesium alloy (AZ91D), the hydrogen gas generation, and the corrosion process. After the alloy was implanted into the distal femur condyle of rabbits for six months, there was no significant inflammation. Accordingly, the response was normal due to the immune system reaction of the host. The study also stated that during the first two months, gas cavities developed, and then during the third month, they dissipated, which is in agreement with other results [33]. Furthermore, it was found that the magnesium alloy (AZ91D) stimulated the formation of new bone and increased its density. However, traces of $\mathrm{Al}$ were found in the blood, kidneys, liver, and other organisms. Additionally, Al species were spotted with residual insoluble corrosion byproducts [33]. Overall, although Mg-Al-based and Mg-REE-based alloys have good mechanical properties and corrosion resistances, they have very poor biocompatibility and hepatoxicity [2,54].

Fan et al. [55] examined the effect of adding $1.35 \mathrm{wt} \%$ cerium (Ce) on grain size refining in a Mg-2Zn-0.5Mn-1Ca. This addition reduced grain size from 125 to $65 \mu \mathrm{m}$. Additionally, it was found that $\mathrm{Ce}$ addition negatively influenced the corrosion resistance of the alloy, displaying the worst performance. In terms of phases distribution and continuity, Ce addition disturbed the formation of $\mathrm{Ca}_{2} \mathrm{Mg}_{6} \mathrm{Zn}_{3}$ compounds and formed two disconnected phases of $\mathrm{Mg}_{2} \mathrm{Ca}$ and $\mathrm{Mg}_{12} \mathrm{CeZn}$. Yang et al. [53] studied the effect of adding different amounts of the rare-earth element dysprosium (Dy) to $\mathrm{Mg}$ on the microstructure, mechanical properties, and corrosion rate. Four alloys of the Mg-Dy alloy system with a concentration of 5, 10, 15, and $20 \mathrm{wt} \%$ Dy were investigated. The effect of heat treatments on the properties of these alloys was also considered. In this case, the alloys were heated at $520^{\circ} \mathrm{C}$ for $24 \mathrm{~h}$ and then quenched in water.

The study concluded that increasing the content of Dy leads to an increase in the tensile yield strength and UTS. The addition of $10 \mathrm{wt} \%$ Dy led to a noticeable improvement in UTS, from $77 \mathrm{MPa}$ to $130 \mathrm{MPa}$. Further addition of Dy showed only a slight increase in the UTS of the alloys and a slight increase in ductility from 4.5 to $5.5 \mathrm{wt} \%$ with additions of up to $5 \mathrm{wt} \%$ Dy. However, further additions of Dy from 15 to $20 \mathrm{wt} \%$ resulted in a drop in alloy 
ductility. In terms of corrosion, the best corrosion resistance was reported for the $10 \mathrm{wt} \%$ Dy alloy. It was of the order of $3 \mathrm{~mm} /$ year in a $0.9 \mathrm{wt} \% \mathrm{NaCl}$ solution. Heat treatment led to alloy softening, but it significantly improved corrosion resistance. Microstructurally, in this alloy, the distribution of Dy became homogeneous, which enhanced the formation of filiform films instead of pitting corrosion. Nonetheless, it was noticed that the overall impurity present in these alloys exceeded the tolerance limit [56].

$\mathrm{Gu}$ et al. [57] characterized the effect of adding various contents of strontium (Sr) with $1-4 \mathrm{wt} \%$ on the strength, cytotoxicity, and corrosion resistance (in vivo and in vitro). The study found that the yield strength, UTS, and degradation rate were increased with an increase in the content of $\mathrm{Sr}$ up to $2 \mathrm{wt} \%$ despite the continuous reduction in ductility with the addition of Sr. Overall, the Mg-Sr alloying system showed very poor biocompatibility with high toxicity.

Bornapour et al. [58] studied the cytotoxicity and corrosion process (in Hank's solution and in vivo) of $\mathrm{Mg}-\mathrm{xSr}(\mathrm{x}=0.3-2.5 \mathrm{wt} \%)$ alloys. The alloys were used as stents and implanted in dogs' femoral arteries. The results showed that $\mathrm{Mg}-0.5 \mathrm{Sr}$ exhibited the lowest degradation rates with no indications of any toxicity. Nevertheless, pitting corrosion was observed on the surface of Mg-0.5Sr combined with a high evolution of hydrogen gas in the early stages.

$\mathrm{Mg}$ alloys containing Ca have also been developed, as Ca has a solubility of $1.34 \mathrm{wt} \%$ in $\mathrm{Mg}$, and it is a non-toxic element with a high allowable daily intake [2]. Different percentages of $\mathrm{Ca}$ have been added to $\mathrm{Mg}$ and their properties disclosed. Zijian Li et al. [46] investigated the effect of adding different amounts of $\mathrm{Ca}(1-3 \mathrm{wt} \%)$ on the mechanical properties and corrosion rates of a commercially pure $\mathrm{Mg}$. In their work, as-cast, hot-rolled, and hot-extruded alloys were prepared and both the mechanical and corrosion properties were determined. Corrosion testing was carried out in vitro (for up to three months) and in SBF for up to $250 \mathrm{~h}$. In this work, $\mathrm{Mg}$-Ca pins were implanted in the femoral and cortical bones of eighteen adult rabbits. It was concluded that increasing Ca content reduces the yield strength, UTS, and ductility (as shown in Table 1). However, the corrosion rate was enhanced, as well as the presence of corrosion byproducts. A further limited enhancement in corrosion rate occurred due to passivation, as a protective layer was formed on the top of the surface. However, this layer had poor coherency. This layer contained high concentrations of carbon, oxygen, magnesium, phosphorus, and chloride. Furthermore, hot extrusion and hot rolling significantly improved corrosion resistance and mechanical strength. Overall, Mg-1Ca exhibited the best mechanical properties, corrosion resistance $\left(2.28 \mathrm{mg} / \mathrm{mm}^{2} /\right.$ year$)$, and biocompatibility when compared with other alloys [47]. However, adding higher amounts of $\mathrm{Ca}$ to $\mathrm{Mg}$ alloys can reduces corrosion resistance in certain solutions. For examples, exposing high-Ca Mg-alloys to SBF forms massive corrosion byproducts [59].

The Mg-Si alloy system shows the presence of $\alpha-\mathrm{Mg}$ and the intermetallic compound $\mathrm{Mg}_{2} \mathrm{Si}$ (Chinese Script) at a rather low Si content (0.003 wt\%). The intermetallic compound $\left(\mathrm{Mg}_{2} \mathrm{Si}\right)$ is rather brittle and highly detrimental when present in coarse sizes. In this alloy system, the optimum mechanical properties of $\mathrm{Mg}$-Si alloys are reported at Si levels of $0.8 \mathrm{wt} \% \mathrm{Si}$, with a yield strength, UTS, and ductility of $52 \mathrm{MPa}, 152 \mathrm{MPa}$, and 9.5\%, respectively [1]. Gu et al. [60] examined the mechanical properties and corrosion performance in in vitro solution and the biocompatibility of several binary alloying systems of magnesium with additions of $1 \mathrm{wt} \%$ of each alloying element (Zn, Mn, Al, Ag, In, Si, Sn, Y, and Zr). The as-cast $\mathrm{Mg}$ binary systems of $\mathrm{Zn}, \mathrm{Si}, \mathrm{Al}, \mathrm{Sn}$, and $\mathrm{Zr}$ had better mechanical properties when compared with pure $\mathrm{Mg}$. Moreover, the corrosion performance of $\mathrm{Mg}$ was reduced when adding $\mathrm{Zn}, \mathrm{Mn}, \mathrm{Al}$, In, and Zr. In contrast, the evolution of hydrogen was significantly reduced with the addition of $\mathrm{Zn}$. The $\mathrm{Mg}-\mathrm{Zn}$ system exhibited acceptable biocompatibility and cell viability to fibroblasts, toxicity to osteoblasts, and blood vessel viabilities.

Another study reviewed a wide range of magnesium-based alloys and the effect of adding different alloying elements on their mechanical properties. It was found that the highest yield strength and ductility can be achieved using Mg-REE-based and Mg- Zn- 
based alloys among other Mg-Al-based, Mg-Si-based, and Mg-Zr-based alloys as reviewed in [1]. The effect of adding small amounts of Mn promotes significant grain refinement in the Mg-Al system. Its effect is rather important, as it hinders the effect of impurities by forming harmless phases. This enhances the corrosion resistance of $\mathrm{Mg}$ alloy systems. Additionally, it has been found that adding Mn moderately increases the yield strength while reducing the UTS and elongation [3,5,16-20,22,52,61,62]. Zinc additions improve mechanical and corrosion performance while reducing hydrogen evolution. However, at high concentrations $(\geq 5 \%)$, Zn leads to poor corrosion resistance and mechanical strength, including reduced biocompatibility $[6-15,23,61,63,64]$.

Yuen et al. [65] studied the theoretical limits of using magnesium alloys as biodegradable materials in biomedical applications. From their work, it was concluded that $\mathrm{Al}$ as an alloying element in Mg-based alloys has the lowest tolerance limit with amounts of $\leq 1 \mathrm{~g}$ per year; by contrast, the tolerance limit for other elements exceeded $10 \mathrm{~g}$ per year.

Zinc ( $\mathrm{Zn})$ has a good solubility (6.2 $\mathrm{wt} \%$ ) in $\mathrm{Mg}$ and has been implemented to improve alloy mechanical properties. $\mathrm{Zn}$ is nontoxic with a recommended daily dosage of $8-11 \mathrm{mg} /$ day for adults $[1,2,66]$. Mg-Zn-based alloys possess good mechanical strength and corrosion resistance. The alloy microstructure consists of the $\alpha-\mathrm{Mg}$ matrix and the $\gamma-\mathrm{MgZn}$ phase. This alloying system exhibits the highest strength $(216.8 \mathrm{MPa})$ and ductility (15.8\%) when $\mathrm{Zn}$ additions of $4 \mathrm{wt} \% \mathrm{Zn}$ are employed. The addition of other alloying elements, such as $\mathrm{Mn}, \mathrm{Si}, \mathrm{Ca}$, and REEs, has been considered. It was found that $\mathrm{Ca}$ additions of up to $0.5 \%$ slightly improve mechanical properties; however, further $\mathrm{Ca}$ additions are detrimental to alloy properties [1].

The addition of $\mathrm{Mn}$ to $\mathrm{Mg}$ - Zn-based alloys improves alloy corrosion resistance due to its ability to counteract the detrimental effect of impurities, such as $\mathrm{Fe}, \mathrm{Ni}$, and $\mathrm{Cu}$, by transferring them to non-active intermetallic compounds. Reduced corrosion rates in a $\mathrm{Mg}-2 \mathrm{Zn}-0.2 \mathrm{Mn}$ alloy exposed to Hank's solution have been reported to be of the order of $0.03 \mathrm{~mm} /$ year. In this case, a protective layer was formed on the surface of the alloy, in addition to stimulating multiple enzyme systems [2,33,46].

Cha et al. [67] investigated the impact of $\mathrm{Ca}$ and $\mathrm{Zn}$ additions on the corrosion behavior of as-cast and extruded Mg. It was found that adding $\mathrm{Zn}$ in amounts of over $1 \mathrm{wt} \%$ to $\mathrm{Mg}$ Ca alloys led to microstructural refinement, improved corrosion resistance, and reduced galvanic effects. In particular, additions of $3 \mathrm{wt} \% \mathrm{Zn}$ provided the highest alloy corrosion performance. The study concluded that refining the microstructure through extrusion led to a reduction in hydrogen generation in in vivo studies.

Zhang et al. [68] tested the effect of alloying with various $\mathrm{Zn}$ contents (1-6 wt\%) on the strength, corrosion behavior, microstructure, and cytotoxicity of a Mg-1Ca alloy. Alloying with $\mathrm{Zn}$ causes changes in the microstructure and mechanical properties. It promotes grain refinement and alters the main mechanical properties. For example, alloying with up to $4 \mathrm{wt} \%$ increased the yield strength by $70 \%$, UTS by $40 \%$, and, finally, its ductility (percent elongation) by $60 \%$. Nevertheless, this study conducted an in vitro corrosion test in Hank's solution at $37{ }^{\circ} \mathrm{C} \pm 0.5$ with a $\mathrm{pH}$ of 7.2-7.4. Mg-1Ca-xZn alloys with $\mathrm{Zn}$ contents of up to $3 \mathrm{wt} \%$ exhibited a lower corrosion rate than that observed in the Mg-1Ca alloy. It was found that these additions of $\mathrm{Zn}$ of up to $3 \mathrm{wt} \%$ did not cause toxicity. Table 1 summarizes the mechanical properties of this alloying system.

Ibrahim et al. [69] investigated the effect of heat treatment on the mechanical strength, microstructure, and corrosion resistance of a Mg-1.2Zn-0.5Ca alloy. In the as-cast alloy, the microstructure consists of an $\alpha-\mathrm{Mg}$ matrix with small spherical eutectic secondary constituents embedded in the matrix and lamellar eutectoids along the grain boundaries. Although the grain size was slightly elongated, overall, the heat treatment promoted a considerable improvement in the mechanical and corrosion properties. Apparently, diffusional mechanisms involving $\mathrm{Zn}$ and $\mathrm{Ca}$ away from the secondary constituents and into the matrix lead to a reduction in alloy micro-galvanic effects. Thus, the reduction in the volume fraction of the secondary phases through the implemented heat treatment was associated with the improved alloy performance. 
Li et al. [2] have investigated Mg-Zn-based alloys and their performance after adding different alloying elements in various concentrations. It was found that the yield strength and UTS increased by 64 and 33\% when increasing the Zn content from 1 to $6 \mathrm{wt} \%$, while the elongation was slightly reduced (by $11 \%$ ). The addition of Mn enhanced the alloy corrosion resistance by eliminating the harmful effect of impurities. Similarly, adding $4 \mathrm{wt} \% \mathrm{Zn}$ to Mg-0.2 Ca led to a high alloy strength and corrosion resistance. In the case of Mg-Si-based alloys, adding $1.6 \mathrm{wt} \% \mathrm{Zn}$ to Mg-0.6Si refined the brittle and coarse Chinese script morphology, thus improving alloy strength while reducing the corrosion rate. This work also considers the role of alloying elements, such as $\mathrm{Zr}$ and $\mathrm{Y}$, in $\mathrm{Mg}$ alloys. The addition of $\mathrm{Zr}$ to $\mathrm{Mg}-\mathrm{Zn}$ alloys, such as $\mathrm{Mg}-5.4 \mathrm{Zn}-0.55 \mathrm{Zr}$, increases the corrosion rate. However, alloying with $\mathrm{Zr}$ is less detrimental than alloying with $\mathrm{Y}$, as in $\mathrm{Mg}-5.6 \mathrm{Zn}-0.55 \mathrm{Zr}$ $0.9 \mathrm{Y}$. Although the corrosion rate in the both former alloys was higher than that of pure $\mathrm{Mg}$, these alloys exhibited improved strength. The study concluded that the development of an appreciable volume fraction of various secondary phases might account for the exhibited performance of these alloys. As for grain refinement, this mechanism is rather effective in improving mechanical properties and corrosion behavior. In the former, the effectiveness of the grain refinement is governed by Hall-Petch (Equation (7)), where the high strengthening coefficient of $\mathrm{Mg}$ alloys $\left(280-320 \mathrm{MPa} \cdot \mu \mathrm{m}^{1 / 2}\right)$ suggests a high potential of using this mechanism to improve alloy strength $[1,70,71]$.

$$
\sigma=\sigma_{0}+k \mathrm{~d}^{-1 / 2}
$$

where $\sigma$ is the yield stress (YS), $\sigma_{0}$ is the material constant, $d$ is the average grain diameter, and $k$ is the strengthening coefficient.

In the same study [2], the exhibited mechanical properties of the different alloying systems fabricated using various processing methods have shown that as-cast $\mathrm{Mg}-\mathrm{Mn}$ $\mathrm{Zn}$ alloys exhibit better strength and ductility (200 $\mathrm{MPa}$ and $15 \%$, respectively) when compared with other alloy systems (Mg-Ca, Mg-Si, Mg-Sr, Mg-Ca-Si, and Mg-Zn-Ca) [2]. This is in agreement with the required properties for applications in bone inserts, which are in the range of $200 \mathrm{MPa}$ UTS, $10 \%$ ductility, and with a corrosion rate of less than $0.5 \mathrm{~mm} /$ year [1,72].

Brooks and Ehrensberger [73] examined the corrosion behavior of $\mathrm{Mg}$ alloys in cell culture media after adding $\mathrm{Zn}, \mathrm{Ca}$, and Sr. The alloys $\mathrm{Mg}-1.34 \mathrm{Ca}, \mathrm{Mg}-2 \mathrm{Sr}, \mathrm{Mg}-1.34 \mathrm{Ca}-$ $3 \mathrm{Zn}$, and $\mathrm{Mg}-1.34 \mathrm{Ca}-3 \mathrm{Zn}-0.2 \mathrm{Sr}$ were heat treated after casting and then extruded and rolled. Additions of $3 \% \mathrm{Zn}$ to $\mathrm{Mg}-1.34 \mathrm{Ca}$ led to the highest alloy corrosion resistance, followed by the Mg-1.34Ca-3Zn-0.2Sr alloy. The study concluded that the addition of $\mathrm{Zn}$ improves the corrosion resistance while reducing the volume fraction of the secondary phases. The addition of $\mathrm{Zn}$ to $\mathrm{Mg}$-Ca alloys produced similar results. Sun et al. [74] tested the mechanical properties and corrosion resistance (in C-SBF) of an as-cast and as-extruded $\mathrm{Mg}-4.0 \mathrm{Zn}-0.2 \mathrm{Ca}$ alloy, finding that $\mathrm{Zn}$ and Ca led to improved mechanical properties and corrosion behavior; in addition, the alloying system displayed good biocompatibility. The exhibited properties of the as-cast alloy were further improved through extrusion. It was found that the extrusion process refined and homogenized the alloy microstructure consisting of $\alpha-\mathrm{Mg}, 2 \mathrm{Ca}-6 \mathrm{Mg}-3 \mathrm{Zn} 3$, and $2 \mathrm{Ca}-5 \mathrm{Mg}-13 \mathrm{Zn}$ by refining the grain size [75] which normally leads to better mechanical properties [70].

The effect of cooling rates on the exhibited properties of three different $\mathrm{Mg}-\mathrm{Zn}-\mathrm{Ca}$ alloys was investigated by $\mathrm{Xu}$ et al. [76]. These alloys, namely, Mg-10Zn-1Ca, Mg-20Zn-1Ca, and $\mathrm{Mg}-6 \mathrm{Zn}-1 \mathrm{Ca}$, were made in the shape of studs by powder metallurgy. Then, they were melted in a mild steel crucible under a controlled environment and subsequently poured into graphite molds and solidified at $\sim 40{ }^{\circ} \mathrm{C} / \mathrm{min}$, in air at $\sim 100{ }^{\circ} \mathrm{C} / \mathrm{min}$, and in liquid nitrogen at $\sim 3000^{\circ} \mathrm{C} / \mathrm{min}$. It was found that rapidly solidified alloys developed a fine grain structure and a connected network of supersaturated secondary phases around the grains (mainly $\alpha-\mathrm{Mg}$ ). The work suggested that a well-distributed network of supersaturated secondary phases can act as an effective coating that inhibits corrosion propagation and, thus, protects the matrix. In contrast, at low cooling rates, the alloy microstructure consisted of 
coarse grain sizes, large secondary phases, and significant impurity segregation. Moreover, it was found that the corrosion resistance of the corrosion-quenched alloys containing small amounts of $\mathrm{Zn} \mathrm{(6 \% )} \mathrm{was} \mathrm{superior} \mathrm{to} \mathrm{that} \mathrm{found} \mathrm{in} \mathrm{alloys} \mathrm{with} \mathrm{high} \mathrm{Zn}$ content [76].

Lisitsyn et al. [77,78] and Ben-Hamu [79] studied the effect of adding $0.2-0.4 \mathrm{wt} \%$ $\mathrm{Ca}$ and/or $0.5-2 \mathrm{wt} \% \mathrm{Si}$ on the corrosion rate (in $3.5 \mathrm{wt} \% \mathrm{NaCl}$ solution saturated with $\left.\mathrm{Mg}(\mathrm{OH})_{2}\right)$ and microstructure of an extruded $\mathrm{Mg}-0.5 \mathrm{Mn}-6 \mathrm{Zn}$ alloy. It was found that the addition of Si induced grain refinement and promoted the development of Chinese script intermetallics. These intermetallics were reduced to a polygonal shape by adding Ca or $1 \mathrm{wt} \% \mathrm{Si}$. The addition of $1 \mathrm{wt} \%$ Si led to an increase in corrosion rates $(0.5$ and $1 \mathrm{wt} \% \mathrm{Si})$ followed by a slight reduction at $2 \mathrm{wt} \% \mathrm{Si}$. However, corrosion resistance was improved when the Chinese script was refined by adding 1-2 wt\% Si or Ca in $0.5 \mathrm{wt} \% \mathrm{Si}$ alloying. In this alloying system, four secondary intermetallic phases $\left(\mathrm{MgZn}_{2}, \mathrm{Mn}_{5} \mathrm{Si}_{3}, \mathrm{Mg}_{2} \mathrm{Si}\right.$, and $\mathrm{CaMgSi}$ ) were identified.

In the case of quaternary alloys, Zhang et al. [80] investigated the microstructure, mechanical properties, and corrosion behavior of $\mathrm{Mg}-\mathrm{Zn}-\mathrm{Mn}-\mathrm{Ca}$. Three as-cast alloys were prepared with the following compositions: $\mathrm{Mg}-1.8 \mathrm{Zn}-1.1 \mathrm{Mn}-0.3 \mathrm{Ca} ; \mathrm{Mg}-2 \mathrm{Zn}-1.2 \mathrm{Mn}-0.5 \mathrm{Ca}$; and $\mathrm{Mg}-1.5 \mathrm{Zn}-1.1 \mathrm{Mn}-1 \mathrm{Ca}$. It was found that the grain size of the $\mathrm{Mg}-1.8 \mathrm{Zn}-1.1 \mathrm{Mn}-0.3 \mathrm{Ca}$ alloy was considerably reduced from 175 to $63 \mu \mathrm{m}$ by increasing the content of $\mathrm{Zn}$ and $\mathrm{Ca}$ by $0.2 \mathrm{wt} \%$. Moreover, this addition resulted in the formation of a $\mathrm{Mg}$ primary phase with a secondary eutectic phase ( $\alpha-\mathrm{Mg}+2 \mathrm{Ca}-6 \mathrm{Mg}-3 \mathrm{Zn})$. The former gave rise to increased yield strength, UTS, and elongation, which increased by 20,16 , and $20 \%$, respectively. However, a further increase in $\mathrm{Ca}$ to $1 \mathrm{wt} \%$ and a reduction in $\mathrm{Zn}$ content down to $1.5 \mathrm{wt} \%$ significantly lowered the alloy strength and ductility. This can be attributed to the formation of an additional secondary brittle phase $\left(\mathrm{Mg}_{2} \mathrm{Ca}\right)$. Overall, the best mechanical and corrosion performance (in Hank's solution at $37^{\circ} \mathrm{C}$ ) was reported for $\mathrm{Mg}-2 \mathrm{Zn}-1.2 \mathrm{Mn}-0.5 \mathrm{Ca}$. Table 1 summarizes the mechanical properties of this alloying system.

Bakhsheshi-Rad et al. [30] investigated the binary and quaternary alloying systems $\mathrm{Mg}-\mathrm{xCa}(\mathrm{x}=2$ and $4 \mathrm{wt} \%)$ and $\mathrm{Mg}-2 \mathrm{Ca}-0.5 \mathrm{Mn}-\mathrm{xZn}(\mathrm{x}=2,4$, and $7 \mathrm{wt} \%)$. The study tested their mechanical properties, microstructure, and corrosion resistance in Kokubo SBF for $240 \mathrm{~h}$ for both alloying systems. It was found that adding $2 \mathrm{wt} \% \mathrm{Ca}$ to pure $\mathrm{Mg}$ reduced the grain size down to $92 \mu \mathrm{m}$ and reduced the ductility by $58 \%$, while the yield strength, UTS, compression strength, and hardness increased by $72,18,27$, and $49 \%$, respectively. Although the corrosion rate in cell culture media magnesium was reduced by adding $2 \mathrm{wt} \%$ Ca (from 8.47 to $6.89 \mathrm{~mm} /$ year), further Ca additions increased the volume fraction of the secondary phase $\left(\mathrm{Mg}_{2} \mathrm{Ca}\right)$ along the grain boundaries, which, in turn, deteriorated both the mechanical properties and corrosion resistance. Alternatively, $\mathrm{Mg}-2 \mathrm{Ca}-0.5 \mathrm{Mn}-$ $4 \mathrm{Zn}$ exhibited the highest mechanical properties among all the examined alloys due to its small grain size structure of $59 \mu \mathrm{m}$ and through solid solution strengthening and the presence of the secondary phases $\mathrm{Mg}_{2} \mathrm{Ca}$ and $\mathrm{Ca}_{2} \mathrm{Mg}_{6} \mathrm{Zn}_{3}$. In particular, the YS, UTS, ductility, compression strength, and hardness significantly increased in comparison to pure Mg (by 202, 94, 20, 85, and 139\%, respectively) [30]. In an Mg-2Ca-0.5Mn-4Zn alloy, the microstructures of $\mathrm{Mg}-\mathrm{Ca}$ and $\mathrm{Mg}-\mathrm{Ca}-\mathrm{Mn}-\mathrm{Zn}$ alloying systems are characterized by the presence of a lamellar eutectic structure of $\alpha-\mathrm{Mg}+\mathrm{Ca}_{2} \mathrm{Mg}_{6} \mathrm{Zn}_{3}+\mathrm{Mg}_{2} \mathrm{Ca}$ at the grain boundaries. This alloy exhibited the second lowest corrosion rate and hydrogen generation after the Mg-2Ca-0.5Mn-2Zn alloy. Moreover, in Mg-2Ca-0.5Mn-4Zn and Mg-2Ca-0.5Mn$2 \mathrm{Zn}$, the degradation rates were reduced to 2.27 and $1.78 \mathrm{~mm} /$ year, respectively [30]. This study also found that $\mathrm{Zn}$ has a maximum solubility of $1.6 \mathrm{wt} \%$ in $\mathrm{Mg}-\mathrm{Zn}$ alloys at room temperature. It is worth mentioning that $\mathrm{Zn}$ in $\mathrm{Mg}$ is a better refinement agent compared with Ca since it possesses a high growth restricting factor $(Q)$ according to Equation (8). Another difference is the steeper slope of the liquidus line, where for $\mathrm{Mg}-\mathrm{Zn}$, its value is $m=6.04{ }^{\circ} \mathrm{C} / \mathrm{wt} \%$, which is larger than the one for the slope in the $\mathrm{Mg}$-Ca alloy system with a slope value of $m=2.12{ }^{\circ} \mathrm{C} / \mathrm{wt} \%$ [30].

$$
Q=m C_{\mathrm{o}}(k-1)
$$


where $Q$ is the growth restricting factor, $m$ is the slope of the liquidus line, $C_{\mathrm{o}}$ is the solute bulk concentration, and $k$ is the solute equilibrium partition coefficient [30].

The solubility limits of $\mathrm{Zn}$ and $\mathrm{Mn}$ in $\mathrm{Mg}$ are 6.2 and $2.2 \mathrm{wt} \%$, respectively. It was reported that the equilibrium phases in the $\mathrm{Mg}-\mathrm{Zn}$ and $\mathrm{Mg}-\mathrm{Mn}$ alloy systems have the presence of five intermetallic compounds: $\mathrm{Mg}_{51} \mathrm{Zn}_{20}, \mathrm{Mg}_{21} \mathrm{Zn}_{25}, \mathrm{Mg}_{4} \mathrm{Zn}_{7}, \mathrm{MgZn}$, and $\mathrm{Mg}_{2} \mathrm{Zn}_{11}$ [81]. Figures 2 and 3 show examples of $\mathrm{Mg}-\mathrm{Zn}-\mathrm{Mn}$ alloying systems.

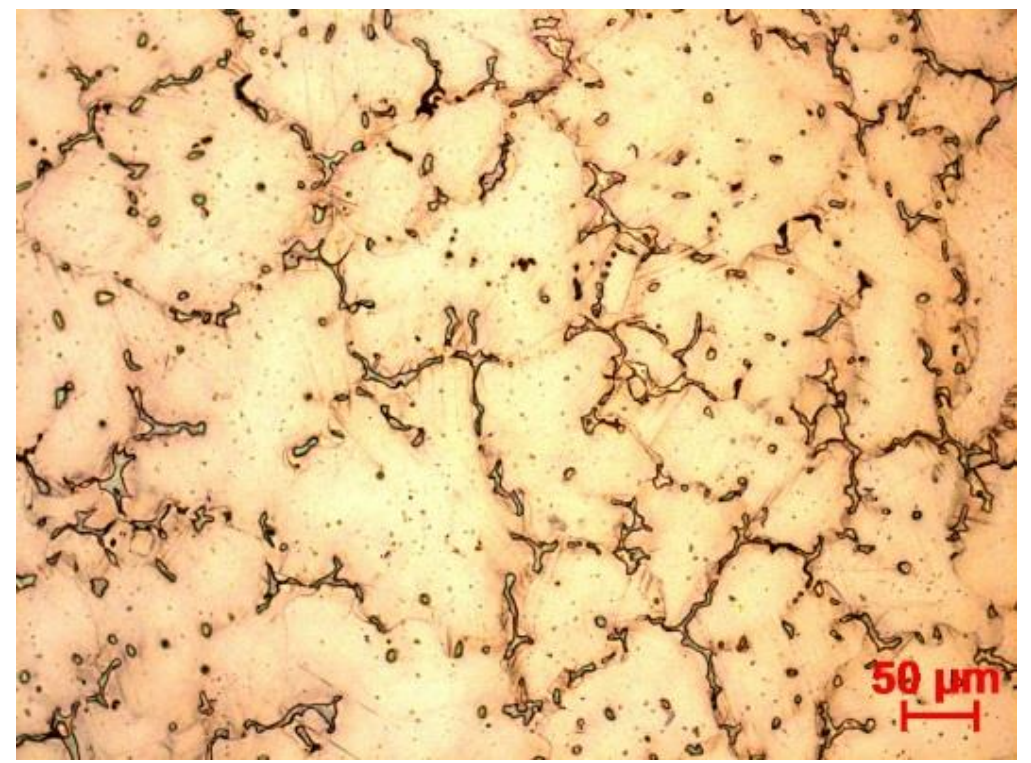

Figure 2. The microstructure of quenched Mg-1Mn-2Zn alloying systems at $200 \times$.

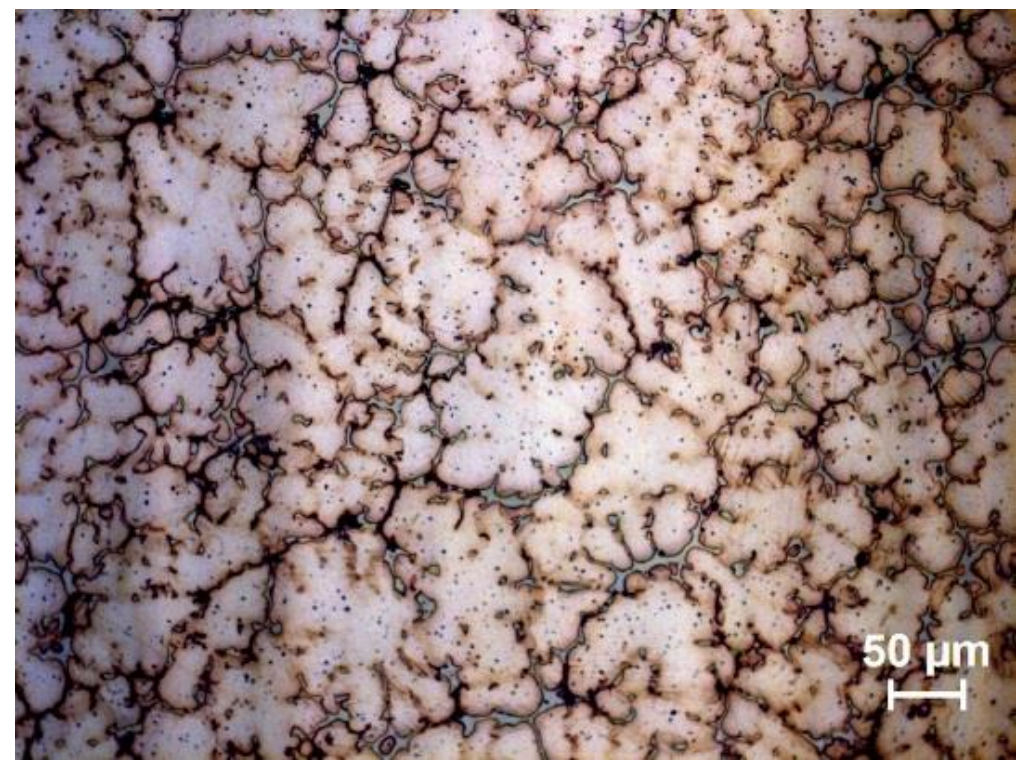

Figure 3. The microstructure of quenched Mg-1Mn- $4 \mathrm{Zn}$ alloying systems at $200 \times$.

From previous works, Agarwal et al. [82] reviewed the corrosion performance, biocompatibility, and surface modification of Mg alloys. They concluded that the presence of $\mathrm{Zn}$ and $\mathrm{Mn}$ contributed to an increased corrosion resistance. Moreover, the use of polymeric coatings was highly effective in enhancing the corrosion performance of $\operatorname{Mg}[82,83]$. Yin et al. [49] considered adding $1 \mathrm{wt} \% \mathrm{Mn}$ to $\mathrm{Mg}$ with various amounts of $\mathrm{Zn}(1-3 \mathrm{wt} \%)$ followed by alloy extrusion. This reduces grain size from 12 to $4 \mu \mathrm{m}$. Additionally, increase in $\mathrm{Zn}$, of $3 \mathrm{wt} \%$, added to the Mg- $1 \mathrm{Mn}-1 \mathrm{Zn}$ alloy system led to the best corrosion behavior [84]. Moreover, $\mathrm{Mg}$ alloys' performance and behavior can also be further enhanced and altered. 
Different studies have shown that heat treatment and various processing methods, such as extrusion, in general, promotes improved mechanical properties and corrosion resistance by means of developing a highly homogeneous and more refined microstructure $[49,85,86]$.

Table 1. Examples of the mechanical properties and grain size of Mg-based alloys.

\begin{tabular}{|c|c|c|c|c|c|}
\hline Composition & Y S (MPa) & UTS (MPa) & $\begin{array}{c}\text { Ductility } \\
(\%)\end{array}$ & $\begin{array}{l}\text { Grain Size } \\
\qquad(\mu \mathrm{m})\end{array}$ & Reference \\
\hline Cortical Bone & $104.9-114.3$ & $35-283$ & $1.07-2.10$ & - & [54] \\
\hline Pure Mg & $20.9 \pm 2.3$ & $86.8 \pm 2.5$ & $13 \pm 1.4$ & - & [64] \\
\hline $\mathrm{Mg}-1 \mathrm{Ca}$ & 40 & 73 & 1.87 & - & [47] \\
\hline $\mathrm{Mg}-2 \mathrm{Ca}$ & 37 & 50 & 1.55 & - & [47] \\
\hline $\mathrm{Mg}-3 \mathrm{Ca}$ & 15 & 40 & 0.6 & - & [47] \\
\hline $\mathrm{Mg}-1 \mathrm{Zn}$ & 25 & 140 & 18 & - & [29] \\
\hline Mg-6Zn & 70 & 210 & 16 & - & [29] \\
\hline Pure Mg & 27.5 & 97.5 & 7.31 & - & [30] \\
\hline $\mathrm{Mg}-2 \mathrm{Ca}$ & 47.3 & 115.2 & 3.05 & - & [30] \\
\hline $\mathrm{Mg}-4 \mathrm{Ca}$ & 34.5 & 77.4 & 2.10 & - & [30] \\
\hline $\mathrm{Mg}-2 \mathrm{Ca}-0.5 \mathrm{Mn}-2 \mathrm{Zn}$ & 78.3 & 168.5 & 7.84 & - & [30] \\
\hline Mg-2Ca-0.5Mn-4Zn & 83.1 & 189.2 & 8.71 & - & [30] \\
\hline $\mathrm{Mg}-2 \mathrm{Ca}-0.5 \mathrm{Mn}-7 \mathrm{Zn}$ & 45.4 & 140.7 & 4.15 & - & [30] \\
\hline Pure Mg & $20.9 \pm 2.3$ & $86.8 \pm 2.5$ & $13 \pm 1.4$ & - & {$[64]$} \\
\hline $\mathrm{Mg}-1 \mathrm{Ca}$ & 39 & $105 \pm 4$ & $4.1 \pm 0.5$ & - & [64] \\
\hline Mg-1Ca-1Zn & 45 & $125 \pm 5$ & $5.7 \pm 1.0$ & - & [64] \\
\hline Mg-1Ca-2Zn & 52 & $143 \pm 5$ & $7.3 \pm 1.5$ & - & {$[64]$} \\
\hline $\mathrm{Mg}-1 \mathrm{Ca}-3 \mathrm{Zn}$ & 57 & $160 \pm 10$ & $8.3 \pm 1.0$ & - & [64] \\
\hline Mg-1Ca-4Zn & 63 & $182 \pm 5$ & $9.1 \pm 2.5$ & - & [64] \\
\hline Mg-1Ca-5Zn & 65 & $173 \pm 5$ & $8.2 \pm 0.5$ & - & [64] \\
\hline Mg-1Ca-6Zn & 67 & $145 \pm 5$ & $4.5 \pm 0.5$ & - & {$[64]$} \\
\hline $\mathrm{Mg}-1.2 \mathrm{Zn}-0.5 \mathrm{Ca}$ & $60 \pm 3.1$ & $121.3 \pm 5.2$ & $3.2 \pm 0.13$ & - & [69] \\
\hline $\begin{array}{c}\mathrm{Mg}-1.8 \mathrm{Zn}-1.1 \mathrm{Mn}- \\
0.3 \mathrm{Ca}\end{array}$ & 60 & 162 & 7.5 & $175 \pm 15$ & [80] \\
\hline $\mathrm{Mg}-2 \mathrm{Zn}-1.2 \mathrm{Mn}-0.5 \mathrm{Ca}$ & 72 & 188 & 9 & $63 \pm 7$ & [80] \\
\hline $\mathrm{Mg}-1.5 \mathrm{Zn}-1.1 \mathrm{Mn}-1 \mathrm{Ca}$ & 80 & 138 & 2.8 & $51 \pm 5$ & [80] \\
\hline $\mathrm{Mg}-4.0 \mathrm{Zn}-0.2 \mathrm{Ca}$ & $60 \pm 1.5$ & $185 \pm 15$ & $12.5 \pm 1.5$ & $100-130$ & [74] \\
\hline Mg-1Mn-1Zn-0.3Al & 44 & 174 & $\sim 12$ & $200-400$ & [77] \\
\hline $\mathrm{Mg}-1 \mathrm{Mn}-2 \mathrm{Zn}-<0.3 \mathrm{Al}$ & $\sim 59$ & $\sim 185$ & $\sim 11$ & - & [77] \\
\hline $\mathrm{Mg}-1 \mathrm{Mn}-3 \mathrm{Zn}-<0.3 \mathrm{Al}$ & $\sim 68$ & $\sim 216$ & $\sim 15.5$ & $50-80$ & [77] \\
\hline $\mathrm{Mg}-0.9 \mathrm{Mn}-0.2 \mathrm{Al}$ & $23.0 \pm 4.3$ & $89.2 \pm 7.6$ & $6.7 \pm 1.0$ & 700-900 & [79] \\
\hline $\mathrm{Mg}-0.9 \mathrm{Mn}-1 \mathrm{Zn}-0.2 \mathrm{Al}$ & $43.6 \pm 5.4$ & $174.5 \pm 1.5$ & $12.1 \pm 1.1$ & - & [79] \\
\hline $\mathrm{Mg}-0.9 \mathrm{Mn}-2 \mathrm{Zn}-0.2 \mathrm{Al}$ & $58.6 \pm 5.7$ & $182.4 \pm 6.8$ & $11.0 \pm 1.0$ & - & [79] \\
\hline $\mathrm{Mg}-0.9 \mathrm{Mn}-3 \mathrm{Zn}-0.2 \mathrm{Al}$ & $65.6 \pm 0.7$ & $218.0 \pm 6.0$ & $15.5 \pm 2.0$ & $50-80$ & [79] \\
\hline $\mathrm{Mg}-0.9 \mathrm{Mn}-4 \mathrm{Zn}-0.2 \mathrm{Al}$ & $65.3 \pm 2.1$ & $199.6 \pm 8.3$ & $11.5 \pm 1.8$ & - & [79] \\
\hline $\mathrm{Mg}-0.9 \mathrm{Mn}-5 \mathrm{Zn}-0.2 \mathrm{Al}$ & $62.2 \pm 1.3$ & $194.6 \pm 7.5$ & $10.5 \pm 1.6$ & - & [79] \\
\hline
\end{tabular}




\section{Conclusions}

This work is a review of the alloying elements in $\mathrm{Mg}$ alloys in biomedical applications. Different alloying elements are considered, such as $\mathrm{Zn}, \mathrm{Ca}$, and $\mathrm{Mn}$. In addition to their effects, the effects of different processing methods, such as extrusion and heat treatment, of binary, ternary, and quaternary Mg-based alloys on grain refinement and mechanical properties are addressed. It was found that the addition of various alloying elements alters the base alloy properties both positively and negatively. These modifications extended from mechanical, microstructural, and corrosion properties. The resulting properties enabled several of these alloys to be used as bioabsorbable implants, such as those for bone replacement. Nonetheless, to explore the full potential of these approaches, alloy brittleness, excessive corrosion, and potential toxicity are among the issues and risk factors that need to be addressed and controlled. Therefore, this work also discussed the role played by various elements in the exhibited corrosion resistance of different $\mathrm{Mg}$-based alloys. Moreover, it can be concluded that $\mathrm{Zn}$ as an alloying element is highly effective in promoting alloy strength and biocompatibility.

Author Contributions: Main author: M.M.J. (Murtatha M. Jamel), supervised by H.F.L.; review and editing: M.M.J. (Mostafa M. Jamel). All authors have read and agreed to the published version of the manuscript.

Funding: This research received no external funding.

Institutional Review Board Statement: Not applicable.

Informed Consent Statement: Not applicable.

Data Availability Statement: Not applicable.

Acknowledgments: I would like to express my appreciation to the University of Wisconsin-Milwaukee; the H.H. Harris Foundation; the Minerals, Metals \& Materials Society (TMS); the American Institute of Mining, Metallurgical, Petroleum Engineers (AIME); the Foundry Educational Foundation (FEF)Northeastern Wisconsin-George J. Barker Memorial; the American Foundry Society (AFS); and the Association for Iron \& Steel Technology (AIST) for honoring and supporting me with their awards.

Conflicts of Interest: The funders had no role in the design of the study; in the collection, analyses, or interpretation of data; in the writing of the manuscript; or in the decision to publish the results. The authors declare no conflict of interest.

\section{References}

1. Chen, Y.; Xu, Z.; Smith, C.; Sankar, J. Recent advances on the development of magnesium alloys for biodegradable implants. Acta Biomater. 2014, 10, 4561-4573. [CrossRef]

2. Li, N.; Zheng, Y. Novel Magnesium Alloys Developed for Biomedical Application. J. Mater. Sci. Technol. 2013, $29,489-502$. [CrossRef]

3. Stulikova, I.; Smola, B. Mechanical properties and phase composition of potential biodegradable $\mathrm{Mg}-\mathrm{Zn}-\mathrm{Mn}-\mathrm{base}$ alloys with addition of rare earth elements. Mater. Charact. 2010, 61, 952-958. [CrossRef]

4. El-Mahallawy, N.; Palkowski, H.; Klingner, A.; Diaa, A.; Shoeib, M. Effect of 1.0 wt. \% Zn addition on the microstructure, mechanical properties, and bio-corrosion behaviour of micro alloyed Mg-0.24Sn-0.04Mn alloy as biodegradable material. Mater. Today Commun. 2020, 24, 100999. [CrossRef]

5. Rosalbino, F.; De Negri, S.; Scavino, G.; Saccone, A. Microstructure and in vitro degradation performance of Mg-Zn-Mn alloys for biomedical application. J. Biomed. Mater. Res. Part A 2013, 101, 704-711. [CrossRef]

6. Hänzi, A.C.; Gerber, I.; Schinhammer, M.; Löffler, J.F.; Uggowitzer, P.J. On the in vitro and in vivo degradation performance and biological response of new biodegradable Mg-Y-Zn alloys. Acta Biomater. 2010, 6, 1824-1833. [CrossRef]

7. Gu, X.; Zheng, Y.; Zhong, S.; Xi, T.; Wang, J.; Wang, W. Corrosion of, and cellular responses to Mg-Zn-Ca bulk metallic glasses. Biomaterials 2010, 31, 1093-1103. [CrossRef]

8. Li, T.; He, Y.; Zhang, H.; Wang, X. Microstructure, mechanical property and in vitro biocorrosion behavior of single-phase biodegradable Mg-1.5Zn-0.6Zr alloy. J. Magnes. Alloy. 2014, 2, 181-189. [CrossRef]

9. Song, Y.; Han, E.; Dong, K.; Shan, D.; Yim, C.D.; You, B.S. Effect of hydrogen on the corrosion behavior of the Mg-xZn alloys. J. Magnes. Alloy. 2014, 2, 208-213. [CrossRef]

10. Song, Y.; Han, E.-H.; Shan, D.; Yim, C.D.; You, B.S. The effect of Zn concentration on the corrosion behavior of Mg-xZn alloys. Corros. Sci. 2012, 65, 322-330. [CrossRef] 
11. Song, Y.; Han, E.; Shan, D.; Yim, C.D.; You, B.S. The role of second phases in the corrosion behavior of Mg-5Zn alloy. Corros. Sci. 2012, 60, 238-245. [CrossRef]

12. Zhang, E.; Yang, L.; Xu, J.; Chen, H. Microstructure, mechanical properties and bio-corrosion properties of $\mathrm{Mg}-\mathrm{Si}(-\mathrm{Ca}, \mathrm{Zn})$ alloy for biomedical application. Acta Biomater. 2010, 6, 1756-1762. [CrossRef] [PubMed]

13. Liu, X.; Shan, D.; Song, Y.; Han, E. Influence of yttrium element on the corrosion behaviors of Mg-Y binary magnesium alloy. J. Magnes. Alloy. 2017, 5, 26-34. [CrossRef]

14. Bi, G.; Li, Y.; Zang, S.; Zhang, J.; Ma, Y.; Hao, Y. Microstructure, mechanical and corrosion properties of Mg-2Dy-xZn ( $\mathrm{x}=0,0.1$, 0.5 and 1 at.\%) alloys. J. Magnes. Alloy. 2014, 2, 64-71. [CrossRef]

15. Li, D.; Wang, Q.; Ding, W. Effects of Ho on the microstructure and mechanical properties of Mg-Zn-Ho-Zr magnesium alloys. Rare Met. 2011, 30, 131-136. [CrossRef]

16. Sajuri, Z.B.; Miyashita, Y.; Hosokai, Y.; Mutoh, Y. Effects of Mn content and texture on fatigue properties of as-cast and extruded AZ61 magnesium alloys. Int. J. Mech. Sci. 2006, 48, 198-209. [CrossRef]

17. Lugo, M.; Jordon, J.B.; Solanki, K.N.; Hector, L.G.; Bernard, J.D.; Luo, A.A.; Horstemeyer, M.F. Role of different material processing methods on the fatigue behavior of an AZ31 magnesium alloy. Int. J. Fatigue 2013, 52, 131-143. [CrossRef]

18. Azeem, M.A.; Tewari, A.; Ramamurty, U. Effect of recrystallization and grain growth on the mechanical properties of an extruded AZ21 Mg alloy. Mater. Sci. Eng. A 2010, 527, 898-903. [CrossRef]

19. Khan, S.A.; Miyashita, Y.; Mutoh, Y.; Sajuri, Z.B. Influence of Mn content on mechanical properties and fatigue behavior of extruded Mg alloys. Mater. Sci. Eng. A 2006, 420, 315-321. [CrossRef]

20. Nam, N.D.; Mathesh, M.; Forsyth, M.; Jo, D.S. Effect of manganese additions on the corrosion behavior of an extruded Mg-5Al based alloy. J. Alloys Compd. 2012, 542, 199-206. [CrossRef]

21. Crosby, W.H.; Likhite, V.V.; O’Brien, J.E.; Forman, D. Serum Iron Levels in Ostensibly Normal People. JAMA 1974, 227, 310-312. [CrossRef]

22. Hou, L.; Li, Z.; Pan, Y.; Du, L.; Li, X.; Zheng, Y.; Li, L. In vitro and in vivo studies on biodegradable magnesium alloy. Prog. Nat. Sci. Mater. Int. 2014, 24, 466-471. [CrossRef]

23. Haghshenas, M. Mechanical characteristics of biodegradable magnesium matrix composites: A review. J. Magnes. Alloys 2017, 5, 189-201. [CrossRef]

24. Liu, X.; Sun, J.; Zhou, F.; Yang, Y.; Chang, R.; Qiu, K.; Pu, Z.; Li, L.; Zheng, Y. Micro-alloying with Mn in Zn-Mg alloy for future biodegradable metals application. Mater. Des. 2016, 94, 95-104. [CrossRef]

25. Li, H.; Zheng, Y.; Qin, L. Progress of biodegradable metals. Prog. Nat. Sci. Mater. Int. 2014, 24, 414-422. [CrossRef]

26. Peron, M.; Torgersen, J.; Berto, F. Mg and Its Alloys for Biomedical Applications: Exploring Corrosion and Its Interplay with Mechanical Failure. Metals 2017, 7, 252. [CrossRef]

27. Moosbrugger, C. Engineering Properties of Magnesium Alloys; ASM: Materials Park, OH, USA, 2017 ; Chapters 1 and 3.

28. Bland, L.G.; Gusieva, K.; Scully, J.R. Effect of crystallographic orientation on the corrosion of magnesium: Comparison of film forming and bare crystal facets using electrochemical impedance and Raman spectroscopy. Electrochim. Acta 2017, 227, 136-151. [CrossRef]

29. Ren, Y.B.; Wang, H.; Huang, J.J.; Zhang, B.C.; Yang, K. Study of biodegradation of pure magnesium. In Key Engineering Materials. Trans Tech Publ. Ltd. 2007, 342, 601-604.

30. Bakhsheshi-Rad, H.; Idris, M.; Abdul-Kadir, M.; Ourdjini, A.; Medraj, M.; Daroonparvar, M.; Hamzah, E. Mechanical and bio-corrosion properties of quaternary Mg-Ca-Mn-Zn alloys compared with binary Mg-Ca alloys. Mater. Des. 2014, 53, 283-292. [CrossRef]

31. Guo, K.W. A Review of Magnesium/Magnesium Alloys Corrosion and its Protection. Recent Pat. Corros. Sci. 2010, 2, 13-21. [CrossRef]

32. Radha, R.; Sreekanth, D. Insight of magnesium alloys and composites for orthopedic implant applications-A review. J. Magnes Alloy. 2017, 5, 286-312. [CrossRef]

33. Atrens, A.; Liu, M.; Abidin, Z.; Ishida, N. Corrosion mechanism applicable to biodegradable magnesium implants. Mater. Sci. Eng. B 2011, 176, 1609-1636. [CrossRef]

34. Pathak, S.S.; Mendon, S.k.; Blanton, M.D.; Rawlins, J.W. Magnesium-Based Sacrificial Anode Cathodic Protection Coatings (Mg-Rich Primers) for Aluminum Alloys. Metals 2012, 2, 353-376. [CrossRef]

35. Zeng, R.; Li, X.; Li, S.; Zhang, F.; Han, E. In vitro degradation of pure Mg in response to glucose. Sci. Rep. $2015,5,13026$. [CrossRef]

36. Kirkland, N.T.; Birbilis, N.; Staiger, M.P. Assessing the corrosion of biodegradable magnesium implants: A critical review of current methodologies and their limitations. Acta Biomater. 2011, 8, 925-936. [CrossRef]

37. Virtanen, S. Biodegradable Mg and Mg alloys: Corrosion and biocompatibility. Mater. Sci. Eng. B 2011, 176, 1600-1608. [CrossRef]

38. Vetter, K.J. Electrochemical Kinetics. Theoretical and Experimental Aspects; Scripta Technica: Berlin, Germany, 1961.

39. Pourbaix, M. Atlas of Electrochemical Equilibria in Aqueous Solutions; NACE International: Houston, TX, USA, 1966.

40. Poinern, G.E.J.; Brundavanam, S.; Fawcett, D. Biomedical Magnesium Alloys: A Review of Material Properties, Surface Modifications and Potential as a Biodegradable Orthopaedic Implant. Am. J. Biomed. Eng. 2014, 2, 218-240. [CrossRef]

41. Elkaiam, L.; Hakimi, O.; Aghion, E. Stress corrosion and corrosion fatigue of biodegradable Mg-Zn-Nd-Y-Zr alloy in in-vitro conditions. Metals 2020, 10, 791. [CrossRef] 
42. Avior, O.; Ben Ghedalia-Peled, N.; Ron, T.; Vago, R.; Aghion, E. The Effect of Ca on In Vitro Behavior of Biodegradable Zn-Fe Alloy in Simulated Physiological Environments. Metals 2020, 10, 1624. [CrossRef]

43. Perets, T.; Ghedalia-Peled, N.B.; Vago, R.; Goldman, J.; Shirizly, A.; Aghion, E. In vitro behavior of bioactive hybrid implant composed of additively manufactured titanium alloy lattice infiltrated with Mg-based alloy. Mater. Sci. Eng. C 2021, $129,112418$. [CrossRef] [PubMed]

44. Clarke, E.G.; Hickman, J. An investigation into the correlation between the electrical potentials of metals and their behaviour in biological fluids. J. Bone Jt. Surg. 1953, 35, 467-473. [CrossRef] [PubMed]

45. Witte, F.; Ulrich, H.; Rudert, M.; Willbold, E. Biodegradable magnesium scaffolds: Part 1: Appropriate inflammatory response. J. Biomed. Mater. Res. Part A 2007, 81, 748-756. [CrossRef] [PubMed]

46. ASM International. ASM Specialty Handbook: Magnesium and Magnesium Alloys; Avedesian, M., Bake, H., Eds.; ASM: Materials Park, OH, USA, 1999; pp. 15, 51, 131-144, 170, 194-200.

47. Li, Z.; Gu, X.; Lou, S.; Zheng, Y. The development of binary Mg-Ca alloys for use as biodegradable materials within bone Biomaterials 2008, 29, 1329-1344. [CrossRef]

48. Witte, F. Reprint of: The history of biodegradable magnesium implants. Acta Biomater. 2015, 23, S28-S40. [CrossRef] [PubMed]

49. Yin, D.; Zhang, E.; Zeng, S. Effect of Zn on mechanical property and corrosion property of extruded Mg-Zn-Mn alloy. Trans. Nonferrous Met. Soc. China 2008, 18, 763-768. [CrossRef]

50. Guo, G.; Song, D.; Jiang, J.; Ma, A.B.; Zhang, L.W.; Li, C. Effect of Synthesizing Temperature on Microstructure and Electrochemical Property of the Hydrothermal Conversion Coating on Mg-2Zn-0.5Mn-Ca-Ce Alloy. Metals 2016, 6, 44. [CrossRef]

51. Hornberger, H.; Virtanen, S.; Boccaccini, A.R. Biomedical coatings on magnesium alloys-A review. Acta Biomater. 2012, 8 , 2442-2455. [CrossRef]

52. Ding, Y.; Wen, C.; Hodgson, P.; Li, Y. Effects of alloying elements on the corrosion behavior and biocompatibility of biodegradable magnesium alloys: A review. J. Mater. Chem. B 2014, 2, 1912-1933. [CrossRef]

53. Witte, F.; Ulrich, H.; Palm, C.; Willbold, E. Biodegradable magnesium scaffolds: Part II: Peri-implant bone remodeling. J. Biomed. Mater. Res. Part A 2007, 81, 757-765. [CrossRef]

54. Gu, X.; Zheng, Y. A review on magnesium alloys as biodegradable materials. Front. Mater. Sci. 2010, 4, 111-115. [CrossRef]

55. Zhang, F.; Aibin, M.A.; Song, D.; Jiang, J.; Lu, F.; Zhang, L.; Yang, D.; Chen, J. Improving in-vitro biocorrosion resistance of Mg-Zn-Mn-Ca alloy in Hank's solution through addition of cerium. J. Rare Earths 2015, 33, 93-101. [CrossRef]

56. Yang, L.; Huang, Y.; Peng, Q.; Feyerabend, F.; Kainer, K.U.; Willumeit, R.; Hort, N. Mechanical and corrosion properties of binary Mg-Dy alloys for medical applications. Mater. Sci. Eng. B 2011, 176, 1827-1834. [CrossRef]

57. Gu, X.N.; Xie, X.H.; Li, N.; Zheng, Y.F.; Qin, L. In vitro and in vivo studies on a Mg-Sr binary alloy system developed as a new kind of biodegradable metal. Acta Biomater. 2012, 8, 2360-2374. [CrossRef]

58. Bornapour, M.; Muja, N.; Shum-Tim, D.; Cerruti, M.; Pekguleryuz, M. Biocompatibility and biodegradability of Mg-Sr alloys: The formation of Sr-substituted hydroxyapatite. Acta Biomater. 2013, 9, 5319-5330. [CrossRef] [PubMed]

59. Kirkland, N.T.; Lespagnol, J.; Birbilis, N.; Staiger, M.P. A survey of bio-corrosion rates of magnesium alloys. Corros. Sci. 2010, 52, 287-291. [CrossRef]

60. Gu, X.; Zheng, Y.; Cheng, Y.; Zhong, S.; Xi, T. In vitro corrosion and biocompatibility of binary magnesium alloys. Biomaterials 2009, 30, 84-498. [CrossRef]

61. Song, G. Control of biodegradation of biocompatable magnesium alloys. Corros. Sci. 2007, 49, 1696-1701. [CrossRef]

62. Guan, R.; Cipriano, A.F.; Zhao, Z.; Lock, J.; Tie, D.; Zhao, T.; Cui, T.; Liu, H. Development and evaluation of a magnesium-zincstrontium alloy for biomedical applications-Alloy processing, microstructure, mechanical properties, and biodegradation. Mater. Sci. Eng. C 2013, 33, 3661-3669. [CrossRef] [PubMed]

63. Zhang, S.; Li, J.; Song, Y.; Zhao, C.; Zhang, X.; Xie, C.; Zhang, Y.; Tao, H.; He, Y.; Jiang, Y.; et al. In vitro degradation, hemolysis and MC3T3-E1 cell adhesion of biodegradable Mg-Zn alloy. Mater. Sci. Eng. C 2009, 29, 1907-1912. [CrossRef]

64. Zhang, S.; Zhang, X.; Zhao, C.; Li, J.; Song, Y.; Xie, C.; Tao, H.; Zhang, Y.; He, Y.; Jiang, Y.; et al. Research on an Mg-Zn alloy as a degradable biomaterial. Acta Biomater. 2010, 6, 626-640. [CrossRef]

65. Yuen, C.K.; Ip, W.Y. Theoretical risk assessment of magnesium alloys as degradable biomedical implants. Acta Biomater. 2010, 6, 1808-1812. [CrossRef]

66. Trumbo, P.; Schlicker, S.; Yates, A.A.; Poos, M. Dietary Reference Intakes for Energy, Carbohydrate, Fiber, Fat, Fatty Acids, Cholesterol, Protein and Amino Acids. J. Am. Diet. Assoc. 2002, 102, 1621-1630. [CrossRef]

67. Cha, P.; Han, H.; Yang, G.; Kim, Y.; Hong, K.; Lee, S.; Jung, J.; Ahn, J.; Kim, Y.; Cho, S.; et al. Biodegradability engineering of biodegradable Mg alloys: Tailoring the electrochemical properties and microstructure of constituent phases. Sci. Rep. 2013, 3, 2367. [CrossRef]

68. Zhang, B.; Hou, Y.; Wang, X.; Wang, Y.; Geng, L. Mechanical properties, degradation performance and cytotoxicity of Mg-Zn-Ca biomedical alloys with different compositions. Mater. Sci. Eng. C 2011, 31, 1667. [CrossRef]

69. Ibrahim, H.; Klarner, A.D.; Poorganji, B.; Dean, D.; Luo, A.A.; Elahinia, M. Microstructural, mechanical and corrosion characteristic of heat-treated $\mathrm{Mg}-1.2 \mathrm{Zn}-0.5 \mathrm{Ca}(\mathrm{wt} \%)$ alloy for use as resorbable bone fixation material. J. Mech. Behav. Biomed. Mater. 2017, 69, 203-212. [CrossRef]

70. Chandrasekaran, D. Grain Size and Solid Solution Strengthening in Metals. Ph.D. Thesis, Stockholm University, Stockholm, Sweden, 2003; pp. 13, 49. 
71. Callister, W.D., Jr. Materials Science and Engineering-An Introduction, 8th ed.; Wiley: Hoboken, NJ, USA, 2010 ; pp. $212-225$.

72. Erinc, M.; Sillekens, W.H.; Mannens, R.G.T.M.; Werkhoven, R.J. Applicability of Existing Magnesium Alloys as Biomedical Implant Materials; TMS (The Minerals, Metals \& Materials Society): Pittsburgh, PA, USA, 2009.

73. Brooks, E.K.; Ehrensberger, M.T. Bio-Corrosion of Magnesium Alloys for Orthopaedic Applications. J. Funct. Biomater. 2017, 8, 38. [CrossRef] [PubMed]

74. Sun, Y.; Zhang, B.; Wang, Y.; Geng, L.; Jiao, X. Preparation and characterization of a new biomedical Mg-Zn-Ca alloy. Mater. Des. 2012, 34, 58-64. [CrossRef]

75. Gao, J.H.; Guan, S.K.; Ren, Z.W.; Sun, Y.F.; Zhu, S.J.; Wang, B. Homogeneous corrosion of high pressure torsion treated Mg-Zn-Ca alloy in simulated body fluid. Mater. Lett. 2011, 65, 691-693. [CrossRef]

76. Xu, Z.; Smith, C.; Chen, S.; Sankar, J. Development and microstructural characterizations of Mg-Zn-Ca alloys for biomedical applications. Mater. Sci. Eng. B 2011, 176, 1660-1665. [CrossRef]

77. Lisitsyn, V.; Ben-Hamu, G.; Eliezer, D.; Shin, K.S. The role of Ca microalloying on the microstructure and corrosion behavior of $\mathrm{Mg}-6 \mathrm{Zn}-\mathrm{Mn}-(0.5-2) \mathrm{Si}$ alloys. Corros. Sci. 2009, 51, 776-784. [CrossRef]

78. Lisitsyn, V.; Ben-Hamu, G.; Eliezer, D.; Shin, K.S. Some particularities of the corrosion behaviour of Mg-Zn-Mn-Si-Ca alloys in alkaline chloride solutions. Corros. Sci. 2010, 52, 2280-2290. [CrossRef]

79. Ben-Hamu, G.; Eliezer, D.; Shin, K.S. The role of Mg 2Si on the corrosion behavior of wrought Mg-Zn-Mn alloy. Intermetallics 2008, 16, 860-867. [CrossRef]

80. Zhang, E.; Yang, L.; Xu, J.; Chen, H. Microstructure, mechanical properties and bio-corrosion properties of Mg-Zn-Mn-Ca alloy for biomedical application. Mater. Sci. Eng. A 2008, 497, 111-118. [CrossRef]

81. Mezbahul-Islam, M.; Mostafa, A.O.; Medraj, M. Essential Magnesium Alloys Binary Phase Diagrams and Their Thermochemical Data. J. Mater. 2014, 2014, 704283. [CrossRef]

82. Agarwal, S.; Curtin, J.; Duffy, B.; Jaiswal, S. Biodegradable magnesium alloys for orthopaedic applications: A review on corrosion, biocompatibility and surface modifications. Mater. Sci. Eng. C 2016, 68, 948-963. [CrossRef] [PubMed]

83. Li, X.; Liu, X.; Wu, S.; Yeung, K.W.K.; Zheng, Y.; Chu, P.K. Design of magnesium alloys with controllable degradation for biomedical implants: From bulk to surface. Acta Biomater. 2016, 45, 2-30. [CrossRef] [PubMed]

84. Dongsong, Y.; Erlin, Z.; Songyan, Z. Effect of Zn content on microstructure, mechanical properties and fracture behavior of Mg-Mn alloy. China Foundry 2009, 6, 43-47.

85. Zhang, D.; Shi, G.; Dai, Q.; Yuan, W.; Duan, H. Microstructures and mechanical properties of high strength Mg-Zn-Mn alloy. Trans. Nonferrous Met. Soc. China 2008, 18, s59-s63. [CrossRef]

86. Zhang, D.; Shi, G.; Zhao, X.; Qi, F. Microstructure evolution and mechanical properties of Mg- $\mathrm{x} \% \mathrm{Zn}-1 \% \mathrm{Mn}(\mathrm{x}=4,5,6,7,8,9)$ wrought magnesium alloys. Trans. Nonferrous Met. Soc. China 2011, 21, 15-25. [CrossRef] 